\title{
Representações identitárias na cultura midiática - o lugar do estereótipo na produção humorística
}

\author{
Identity representations in the media culture - the role of stereotype in a \\ comedy show production
}

\author{
Representaciones de identidad en la cultura de medios - el lugar del estereotipo \\ en la producción humorística
}

\author{
Ricardo Pavan ${ }^{1}$ \\ Recebido em 17/10/2019; revisado e aprovado em 11/03/2020; aceito em 26/05/2020 \\ DOI: http://dx.doi.org/10.20435/inter.v21i4.2777
}

\begin{abstract}
Resumo: Partimos da compreensão de que as estratégias de produção usadas nos humorísticos exprimem identificações estereotipadas do contexto sociocultural em que é reproduzido. Não tomamos a ideia de identidade como estática, natural, mas como constantemente reinventada e investida de novos significados. Embora leve-se em conta que nem todos se encontram sob uma mesma linguagem cultural, as perspectivas indicam que, ao consumirem um produto midiático humorístico, os espectadores refletem um sistema de representação do mundo. A conclusão é a de que a tessitura dos processos comunicacionais envolvidos nessa relação depende de uma série de dispositivos que acionam repertórios de significados e perspectivas de vinculação social.
\end{abstract}

Palavras-chave: humor e estereótipos; programas humorísticos; cômico na mídia; humor midiático.

Abstract: The study came from the understanding that production strategies applied in comedy shows express stereotyped identifications of the socio-cultural context in which they are reproduced. The idea of identity is not perceived as static, natural, but as constantly reinvented and provided with new meanings. Although not all comedy shows are placed under the same cultural language, prospects indicate that the audience, by consuming a humorous media product, reflects a representation system of the world. As a final point, the communication processes structure involved in this relationship depends on several instruments that trigger the repertories of social connection meanings and perspectives.

Keywords: humor and stereotypes; comedy shows; comic in the media; humor media.

Resumen: Partimos de la comprensión de que las estrategias de producción utilizadas en el humor expresan identificaciones estereotipadas del contexto sociocultural en el que se reproduce. No tomamos la idea de identidad como estática, natural, sino como constantemente reinventada e invertida con nuevos significados. Aunque debe tenerse en cuenta que no todos están bajo el mismo lenguaje cultural, las perspectivas indican que, al consumir un producto de medio humorístico, los espectadores reflejan un sistema de representación del mundo. La conclusión es que la estructura de los procesos comunicacionales involucrados en esta relación depende de una serie de dispositivos que desencadenan repertorios de significados y perspectivas de apego social. Palabras clave: humor y estereotipos; programas humorísticos; cómico en los medios de comunicación; humor mediático.

\section{INTRODUÇÃO}

Enquanto campo de saber, as ciências da comunicação, assim como todas as outras que compõem as ciências humanas e sociais, não param de reformular seus objetos e perspectivas de análise, uma vez que as transformações socioculturais pressionam incessantemente no sentido de modificar a percepção da realidade social. Desse modo, o campo de conhecimento nem sempre é capaz de produzir previsões confiáveis, porque os seres humanos alteram o seu comportamento em relação ao saber que sobre ele se obtém.

\footnotetext{
${ }^{1}$ Universidade Federal de Goiás (UFG), Goiânia, Goiás, Brasil.
} 
O pensamento se baseia no argumento de Sousa Santos (1988), para o qual a concepção humanística das ciências sociais coloca a pessoa, enquanto autor e sujeito do mundo, no centro do conhecimento, mas, ao contrário das humanidades tradicionais, introduz o que se costumava designar de natureza no centro da pessoa ${ }^{2}$. É fato de que a convergência das mais variadas disciplinas das ciências sociais para os estudos na área da cultura, ao mesmo tempo que abre novos horizontes e perspectivas no campo epistemológico e metodológico, suscita tensões e incertezas diante da pluralidade dos objetos e da multiplicidade teórica. Nesse olhar, a noção de cultura deixa de se constituir num complexo unificado coerente e se transforma num conjunto de significados, atitudes e valores partilhados, construídos socialmente.

Na reflexão científica contemporânea, encontram-se recentes e significativas possibilidades de abordagem do campo da comunicação, capazes de problematizar com profundidade o papel das mídias na vida social. Parte-se da compreensão de que o processo comunicacional é constituído pela articulação de diferentes dimensões. Trazendo a questão para o campo das mídias, o desafio passa a ser o de entender como a comunicação opera, como ela estabelece relações com o mundo real, dos indivíduos/grupos sociais e suas diversidades.

No caso específico da análise proposta, para a investigação de uma temática tão esparsa como o humor no campo da comunicação, é preciso iniciar-se de uma perspectiva que abarque diferentes saberes dos campos sociais, no propósito de municiar-se com ferramentas teórico-metodológicas que permitam refletir acerca da relação entre o gênero humorístico, o contexto midiatizado e o cenário sociocultural. Se a cultura é mesmo uma construção, uma etapa em cada momento, como sugere García-Canclini (2003), também se pressupõe que ela resiste à medida que consegue interagir com as demais culturas, fazendo valer suas práticas e significações. E é no âmbito midiático que se projeta, a um só tempo e com a mesma intensidade, esse fulcro de contradições, constituindo-se num privilegiado espaço de negociação de sentidos no mundo contemporâneo.

Na direção de discordância com a manutenção de padrões estéticos que se perderam com o desenvolvimento das forças produtivas, Martín-Barbero (2003) observa esse tipo de produção midiática como um espaço de interpelação dos sujeitos sociais. Para Salomão (2003), as leituras indicam a opção do espectador não somente por um modo de se mostrar o mundo, mas designam definições em "identificações e representações que se estabelecem a partir do político e do ideológico, da ética e a moral, do estético e o psicológico" (SALOMÃO, 2003, p. 45).

Woodward (2007), ao investigar o funcionamento dos processos simbólicos nas tradições identitárias, considera que "não existe nada inerentemente sagrado nas coisas. Os artefatos e ideias são sagrados apenas porque são simbolizados e representados como tais" (WOODWARD, 2007, p. 40). E, como observa Silva (2007), os diferentes grupos sociais utilizam a representação para forjar a sua identidade e as identidades de outros grupos sociais.

\section{SOBRE HUMOR E ESTEREÓTIPOS}

O conceito de humor é demasiado complexo para ser estudado somente nas ciências da comunicação. Se forem consideradas as pesquisas recentes nesse âmbito, verifica-se que a abordagem da temática é bem mais intensa, aliás, em campos como a psicologia, a história,

\footnotetext{
2 A observação é de Sousa Santos (1988), que amplia sua reflexão ao dizer que, para os estudos que levam em conta essa linha de pensamento, não há natureza humana, porque toda natureza é humana.
} 
a antropologia e a linguística ${ }^{3}$. O propósito aqui, no entanto, é o de trazer essas diferentes perspectivas para o campo comunicacional.

Mais que simplesmente fazer rir, o humor quase sempre reflete percepções culturais mais profundas e, como nota Driessen (2000), oferece um instrumento poderoso para a compreensão dos modos de pensar e sentir moldados pela cultura. Um conceito restrito para o humor pode levar a falsas respostas, uma vez que se trata de um tema complexo e de difícil exploração em termos multiculturais e temporais. A própria noção de humor é relativamente recente na história da humanidade. De acordo com Bremmer e Roodenburg (2000), a terminologia foi registrada pela primeira vez na Inglaterra em 1682, já que, antes disso, significava disposição mental ou temperamento.

O humor, que originalmente significava líquido em referência às substâncias líquidas que circulavam pelo corpo, foi definido como um tipo de estímulo que tende a desencadear aquele reflexo motor, produzido pela contração coordenada de quinze músculos faciais acompanhado pela alteração da respiração e por certos ruídos irreprimíveis. (SALIBA, 2002, p. 19).

A palavra humor tem sido relacionada mais frequentemente com disposição para o riso, ou com a capacidade de apreciar ou expressar o que é cômico. Em O nome da rosa, Umberto Eco (1985) enfatiza a demonização do riso pela religião na Idade Média, compreendido como uma manifestação de mediocridade e vulgaridade. O riso, segundo a igreja, poderia contaminar as pessoas sérias, pois afastava o homem de Deus, da razão e do caminho da sabedoria ${ }^{4}$. Skinner (2002) acrescenta que o riso começou a ser visto, naquela época, como um tipo de grosseria nos dois sentidos do termo: tanto como um exemplo de incivilidade e indelicadeza quanto como uma reação descontrolada e, portanto, bárbara, que precisava, numa sociedade educada, ser dominada e, de preferência, eliminada.

Por meio do humor, é possível estabelecer uma mudança de perspectiva em relação aos problemas do cotidiano. Freud (1977) entende que o humor tem um elemento de libertação e pode ser considerado algo que flui, envolvendo características básicas do indivíduo que se expressam no corpo, no temperamento, em reações emocionais, em maneiras de sentir, pensar e de espírito. 0 estudo do psicanalista Os chistes e sua relação com o inconsciente ${ }^{5}$, publicado em 1905, é até hoje um dos mais referenciados nas investigações sobre o funcionamento do humor. O autor entende que cabe não somente ao locutor o processo instaurador do humor, mas também ao receptor, compreendendo o conjunto a partir da mesma perspectiva. Freud (1977) sugere que o humor só acontece quando o outro a quem se dirige está preparado para entender a mensagem, funcionando, assim, como um diálogo ou como uma interlocução dos inconscientes.

Em seu livro Comicidade e riso, escrito em 1946, Vladimir Propp (1992) criticava a análise restrita do humor aos materiais do século XIX e meados do século XX, notando que era preciso ampliar o olhar sobre o cômico, não apenas a obras clássicas e aos melhores exemplos do

\footnotetext{
3 Alguns deles ofereceram relevantes subsídios para a realização desta pesquisa: Bakhtin (2002), Bergson (2001), Bremmer e Roodenburg (2000), Minois (2003), Possenti (1998), Saliba (2002), entre outros.

${ }^{4}$ Como referência às diversas concepções de humor, poderíamos lembrar o célebre embate filosófico entre o padre beneditino Jorge, contrário ao ato de rir e às coisas que fazem rir, classificando o riso como uma "deformação do rosto, suscitador de um incentivo à dúvida", e o franciscano Guilherme de Baskerville, para quem o "riso é próprio do homem, é sinal de sua racionalidade, se ele incentiva a dúvida, às vezes é justo duvidar" (ECO, 1985, p. 158-9).

${ }^{5}$ Chiste é uma expressão mais utilizada em Portugal. No Brasil, o termo empregado por Freud pode ser coloquialmente traduzido por piada, um dito engraçado.
} 
folclore, mas também às revistas humorísticas e aos folhetins contemporâneos que refletiam a vida cotidiana. Bremmer e Roodenburg (2000) observam que, até os dias de hoje, a atenção acadêmica dada ao humor em geral se concentrou em obras de literatura ou nos contos populares, sendo que raras vezes esses estudos situam com clareza os textos dentro do grupo ou da cultura em que devem ter transitado. Gurevich (2000) concorda com esses apontamentos:

Uma história do humor me parece uma questão bastante discutível, já que os estudiosos que tentam elucidar aspectos das atitudes mentais necessariamente têm que extrair esses padrões de uma visão de mundo mais abrangente, do complexo formado pelo comportamento humano e pelo conjunto de valores. Entretanto, tão logo tentamos extrair alguns aspectos da realidade de seus contextos vitais, surge o perigo de destruirmos, por meio deste procedimento, a verdadeira imagem dessa realidade. (GUREVICH, 2000, p. 83).

Em pesquisas mais recentes, o humor e o riso têm sido abordados sob uma perspectiva mais complexa, que também procura dar conta de sua natureza sociológica. Mesmo assim, as divergências em torno desses conceitos se multiplicam, especialmente entre historiadores e antropólogos. Driessen (2000) relativiza a proximidade entre o humor e o riso, salientando que os dois, embora intimamente ligados, não devem ser considerados inseparáveis: "É amplamente sabido que se pode apreciar uma piada sem de fato rir, e que se pode rir por outras razões que não seja a compreensão de uma piada" (DRIESSEN, 2000, p. 135). Para Possenti (1998), o que caracteriza o humor é muito provavelmente o fato de que ele permite dizer alguma coisa mais ou menos proibida, mas não necessariamente crítica, no sentido corrente, isto é, revolucionária, contrária aos costumes arraigados e prejudiciais. Essa condição, porém, não o impede de explorar a transgressão social: "Ao jogar com contraste abrupto e conciso de dois sistemas de significados, o humor escancara as diferenças entre a espontaneidade da vida cotidiana e o formalismo das instituições sociais, deixando transparecer os vícios do personalismo crônico nas relações humanas" (SALIBA, 2002, p. 304).

Ferrari (1994) considera o humor uma dimensão originária de relacionamento com a realidade, a que não temos acesso direto, apenas obliquamente, por meio de suas realizações. Humor é uma atribuição de sentido que está vinculada aos quadros de relevância compartilhados, aos costumes, hábitos, à rede de significados que sustenta uma cultura. Para atribuir sentido e achar engraçado, é preciso estar de algum modo envolvido ou ser conhecedor do contexto ao qual o texto recorre.

Nesse cenário, são criados e fixados trejeitos e falas que são reconhecidos pelos espectadores. Saliba (2002) faz uma reflexão em torno dos estereótipos e seu uso frequente em textos como a anedota:

A anedota, além de exemplificar alguns procedimentos utilizados para produzir o efeito cômico - a concisão, a antítese, o uso de estereótipos -, parece-nos bastante representativa do surpreendente impacto que tais simplificações exerceram sobre a imaginação coletiva. [...] Para chegar aos estereótipos sugeridos pela anedota, contudo, foi necessária uma concentração de significados históricos acumulados numa brutal redução - na qual todos se reconheçam. A compreensão decorre de um acordo prévio da memória coletiva, que sintetiza todo o efeito da representação nas rápidas simplificações da anedota. O estereótipo é uma espécie de prêt-à-porter do humorismo, que, por sua vez, se alimenta desta sua intrínseca vocação de juntar fragmentos do passado e concentrá-los naquele instante rápido e fugidio da anedota. (SALIBA, 2002, p. 16).

O linguista Sírio Possenti (2005) observa que não se pode falar de discurso humorístico sem considerar a relevância dos estereótipos em seu funcionamento. Assim, caso se queira ler 
os discursos humorísticos também como documentos, deve-se passar necessariamente pela questão de saber em que medida os estereótipos representam também verdades. Ele lembra que o humor vive em grande medida da exploração de estereótipos e aponta duas razões para isso: "Uma de ordem cognitiva, tem a ver com a facilidade de interpretação que o estereótipo propicia; outra, de ordem genericamente social, e que é constitutiva dos gêneros humorísticos, dado que, em geral, os estereótipos são de alguma forma negativos" (POSSENTI, 2005, p. 1-2).

Para Saliba (2002), mesmo que os utilizem e usem, os humoristas sempre souberam que, no fundo, os estereótipos também paralisam a história. Tanto assim que, para renovar seu estoque cômico, serão forçados, com o surgimento das mídias, a submeter as referidas simplificações a um intenso processo de desmistificação, destruição, reciclagem e criação de novos estereótipos. 0 autor acrescenta que os humoristas atuaram nas duas pontas do processo de formação simbólica dos estereótipos, mas a missão de destruir foi mais forte, dadas as próprias características de impermanência, de um certo descompromisso com projetos de longo prazo e a necessidade de renovação constante da produção humorística.

Se as anedotas revelam a pobreza das representações estereotipadas e dos clichês, Saliba (2002) compreende que também indicam uma cultura tácita, um conjunto de imagens simplificadas que sempre chamaram atenção dos historiadores, já que exercem uma grande fascinação sobre a imaginação coletiva. Uma análise mais aprofundada das construções humorísticas permitirá o entendimento de como o humor exibido é capaz de traduzir tradições e contradições presentes no imaginário social, explorando identidades culturais que representam uma parte do universo sociocultural em que é veiculado. Por outro lado, permitem relativizar a ideia de identidade em tempos de desterritorialização.

É importante salientar a ideia dos estereótipos porque eles atuam na construção da identidade cultural, e a mídia, como construtora de uma variedade de discursos, contribui para sua consolidação. Segundo Rocha (2003), a tendência do estereótipo é a generalização excessiva, capaz de gerar crenças consensuais a respeito de características marcantes que identificam todos os membros de uma nacionalidade, região, religião, grupo étnico, entre outros. Por meio dos estereótipos, torna-se possível avaliar como o discurso humorístico apropria-se de construções identitárias e as dissemina sem que seja estabelecida uma relação com o real-histórico.

A recorrência a estereótipos identitários, fixados e enrijecidos em algumas situações por tradições bem recentes, é reforçada pela disseminação da cultura midiática. Embora tenham um caráter local/regional, os discursos humorísticos em torno dos personagens se prendem, muitas vezes, à questão nacional, criando generalizações abusivas. Assim, conduzidas pelas próprias características intrínsecas de concisão, condensação e simultaneidade, as representações humorísticas participaram ativamente desse processo de invenção da imaginação nacional, construindo tipos, visuais ou verbais, e fomentando estereótipos.

\section{SIGNIFICAÇÕES ENTRE A COMICIDADE E O RISO}

A impossibilidade de uma definição exata do riso passa pela sua ampla caracterização por diversos autores ${ }^{6}$. Entendido como uma visão, ao mesmo tempo particular e universal, o riso

\footnotetext{
${ }^{6}$ A gama descritiva é tão rica quanto a gama semântica. Em todas as línguas, uma infinidade de expressões, de fonética sugestiva, dá conta das inúmeras nuances do riso, e a classificação dos tipos de riso é de extraordinária riqueza, do sorriso à gargalhada, da troça ao riso senil, passando pelo riso maníaco, riso até as lágrimas, riso
} 
percebe a generalidade de forma diferente, embora não menos importante do que o sério. "O riso tem um profundo valor de concepção de mundo, é uma das formas capitais pelas quais se exprime a verdade sobre o mundo na sua totalidade, sobre a história, sobre o homem" (BAKHTIN, 2002, p. 57). Nesse sentido, o gênero humorístico é compreendido por suas essências e vem opor-se aos conflitos da realidade, como forma de extrair o riso das pessoas a partir de situações da vida cotidiana. Essa condição assinala a relevância das representações humorísticas no processo de construção/ desconstrução do imaginário popular e, também, a contribuição para transformá-lo e desmistificá-lo.

São várias as concepções que se associam ao riso e ao humor, geralmente ambíguas. Tornase interessante, então, salientar uma abordagem quanto à pluralidade semântica do gênero. Este contexto valoriza a interpretação do sentido humorístico de cada povo e cada momento histórico, explicitando que a sua forma de expressão pode não ser acessível ou apreciada em outras épocas. O emprego das explicações clássicas do significado, ancoradas na procura da essência do cômico, persiste até hoje, sem que consiga remeter às suas origens. Apesar de o humor ser amplamente estudado, teorizado e discutido, permanece difícil distinguir os aspectos para sua definição. O termo humor surge para designar não somente uma disposição de espírito, e sim uma posição do espírito. Surge desta concepção o espaço do riso, que dissimula o sério e permite a existência simultânea de sentimentos antagônicos.

O riso revelou de maneira nova o mundo, no seu aspecto mais alegre e mais lúcido. Seus privilégios exteriores estão indissoluvelmente ligados às suas formas exteriores, constituem de alguma maneira o reconhecimento exterior desses direitos interiores. Por essa razão o riso, menos que qualquer outra coisa, jamais poderia ser um instrumento de opressão e embrutecimento do povo. Ninguém conseguiu jamais torná-lo inteiramente oficial. Ele permaneceu sempre como uma arma de liberação nas mãos do povo. (BAKHTIN, 2002, p. 81).

De outro lado, embasando-se nos estudos de Bergson (2001), pode-se pensar o humor como um plano de efeitos imediatos da sanção moral ou social. Isto se torna ainda mais nítido quando o emissor atinge a complexidade da consciência do seu público; a produção humorística é, então, apreciada pela sua qualidade de converter a seriedade da vida em algo que nos é mais fácil aceitar. Esse disfarce da seriedade caracteriza a habilidade do humor em modificar as disposições de espírito do homem.

O recorrente destronamento de valores morais acaba trazendo algumas verdades nuas, carregadas de apelo ao riso: "A racionalidade do cômico difere da racionalidade pela qual normalmente apreendemos o mundo, e essa diferença - quase quantificada como em uma operação matemática - é a própria causa do riso" (ALBERTI, 2002, p. 30). Ele tem existência no espaço do não sério, onde se desenvolve uma ordem totalmente diferente da do mundo sério e ordinário.

É da própria natureza do humor se fundamentar nas contradições, quase sempre de modo inesperado, para tentar descobrir onde está a "mentira" no fato apresentado como verdadeiro, a fim de possibilitar o surgimento de outro efeito, muitas vezes oculto. Compreende-se que

amarelo, riso idiota, riso a bandeiras despregadas, riso grosseiro, riso forçado, riso grande, riso triunfante, riso silencioso. Psicologicamente, é um fenômeno reflexo vital, sobre o qual a vontade tem pouco controle. Controlado pela boca, é um modo de comunicação pré-linguística já codificado, e as vogais utilizadas (há, há, há, he, he, he, hi, hi, hi, ho, ho, ho, hu, hu, hu) têm uma significação já estudada em obras do século XVI. O que o século XX introduziu, em compensação, é a quase certeza da existência de um centro do riso no cérebro, mesmo que existam dúvidas quanto ao lugar preciso. Até pouco tempo atrás, situava-se esse centro no córtex cerebral direito, região de atividades de síntese, por oposição ao lado esquerdo, região de atividades lógicas e analíticas (MINOIS, 2003, p. 615-6). 
esse método implique um processo essencialmente criativo, que vai acarretar a comicidade necessária para que o humor se realize. "O cômico, por sua condição ridícula, não desperta desejos de identificação, mas de distanciamento, levado a efeito através da descarga elétrica do riso" (LUNARDELLI, 1996, p. 22). Aqui, é possível que se perceba, ao desestabilizarmos o suposto equilíbrio entre os elementos da existência, que o humor se revela nas pequenas, cotidianas e rotineiras situações e que a inversão dessas é que alcança a comicidade. Georges Bataille, em conferência realizada em 1953, corrobora essa premissa quando apresenta sua própria definição do cômico e aponta para sua significação:

[...] o desconhecido faz rir. Faz rir por passar muito bruscamente, repentinamente, de um mundo onde cada coisa é bem qualificada, onde cada coisa é dada em sua estabilidade, em uma ordem estável em geral, para um mundo onde de repente nossa segurança cai por terra, onde percebemos que essa segurança era enganadora, e que, lá onde havíamos acreditado que toda coisa era estritamente prevista, ocorreu o imprevisível, um elemento imprevisível e derribador, que nos revela, em suma, uma verdade última: que as aparências superficiais dissimulam uma perfeita ausência de resposta a nossa expectativa. (BATAILLE apud ALBERTI, 2002, p. 201).

Em seu estudo sobre Hobbes e a teoria clássica do riso, Skinner (2002) revela que a comédia almeja ridicularizar certos tipos de afetações e observa que os vícios mais suscetíveis ao escárnio são a avareza, a hipocrisia e a vaidade. Ao mesmo tempo, estabelece uma forte distinção entre o cômico e o burlesco ${ }^{7}$. O autor se vale de pensadores da Idade Média para afirmar que a figura do "sovina" sempre rendeu um dos melhores personagens para a comédia. "Um dos defeitos que mais merecem ser ridicularizados é a sovinice dos homens de idade, porque a avareza desfigura e torna monstruoso qualquer homem" (SKINNER, 2002, p. 38). Referindo-se especificamente à noção de Hobbes, Skinner entende que a sensação de superioridade provocada pelo riso pode surgir não apenas da comparação de si com as fraquezas alheias, mas também das próprias fraquezas em tempos passados.

Na Itália medieval, além da presença do "bobo da corte", havia a brincadeira de mau gosto conhecida como beffa (BURKE, 2000). As apresentações das brincadeiras de mau gosto, segundo o pesquisador, foram famosas nas cortes italianas; seus lugares preferidos eram as tabernas, e ocorriam principalmente no período de carnaval, tendo em vista que Florença era considerada la capitale de la beffa. 'A beffa muitas vezes não era 'pura' diversão, mas um meio de humilhar, envergonhar e na verdade aniquilar socialmente rivais e inimigos. Tratava-se de uma cultura em que a honra e a vergonha eram valores dominantes" (BURKE, 2000, p. 103). Conclui o historiador que o hábito cultural acabou sendo reprimido aos poucos, dando lugar, nos séculos XVI e XVII, a uma graça espiritual e humor verbal usufruídos na elite social italiana. A mudança, no entanto, não significou o desaparecimento das brincadeiras grosseiras e agressivas que caracterizam a comicidade entre os elementos caricatos dos personagens dessa nacionalidade ou descendência étnica ${ }^{8}$.

\footnotetext{
7 Baseando-se em Henry Fielding, o autor comenta sobre o contraste do riso produzido pela sátira (desdenhoso e escarnecedor) e o riso produzido pelo burlesco (simpático) (SKINNER, 2002, p. 46-7).

8 O que pode muito bem ser verificado na antológica obra cinematográfica intitulada Brutti, sporchi e cattivi (Feios, sujos e malvados), dirigida por Ettore Scola (1976), que revela as mazelas do país com sordidez. O filme se transforma em uma comédia justamente por mostrar crueldades e situações de extrema feiura que acontecem com uma família que reside na periferia de Roma.
} 
Uma das condições de explorar o ridículo das coisas é a presença do exagero, que, para Propp (1992), aparece quando se desnuda um defeito. Entre os dispositivos utilizados para realçar a comicidade dos personagens humorísticos contemporâneos, vale mencionar a caricatura, cujo conceito antecede ao do próprio humor ${ }^{9}$. Para o autor, a caricatura se transforma numa das principais estratégias cômicas, capazes de permitir o riso instantâneo no público:

As diferenças biológicas individuais são ridículas quando percebidas como deformidades que transgridem a harmonia da natureza. Isso esclarece por que são ridículas as deformações dos rostos humanos nos espelhos curvos. Narizes exagerados e proeminentes, bochechas extremamente gorduchas, enormes orelhas de abano, uma expressão do rosto completamente inusitada, sobretudo quando ri de modo que a boca chegue até as orelhas - tudo isso constitui uma deformidade que suscita o riso como também os outros tipos de deformidade e desproporção. (PROPP, 1992, p. 64-5).

Com relação à paródia, Propp observa que ela se manifesta na imitação das características exteriores de um fenômeno qualquer de vida, de modo a ocultar ou negar o sentido interior daquilo que é submetido à parodização: "É um dos instrumentos mais poderosos de sátira social, mas ela só é cômica quando revela a fragilidade interior do que é parodiado" (PROPP, 1992, p. 87). Diferentemente da caricatura, a paródia não tem a origem na produção humorística num sentido simplesmente imagético, mas também é capaz de explorar outras possibilidades criativas, abrangendo diferentes aspectos cômicos do personagem/objeto enfocado:

A paródia consiste num exagero cômico na imitação, uma reprodução exageradamente irônica das peculiaridades características individuais da forma deste ou daquele fenômeno que revela sua comicidade e reduz seu conteúdo. [...] É possível, a rigor, parodiar tudo: os movimentos e as ações de uma pessoa, seus gestos, o andar, a mímica, a fala, os hábitos de sua profissão e o jargão profissional; é possível parodiar não só uma pessoa, mas também o que é criado por ela no campo do mundo material. (PROPP, 1992, p. 84-5).

O historiador francês Georges Minois (2003), ao analisar o tema no século XX em seu História do riso e do escárnio, observa que o riso tornou-se um antiestresse infalível, capaz de milagrosas virtudes terapêuticas. Ele se vale do termo "sociedade humorística", cunhado por Gilles Lipovesty, para considerar o riso como uma espécie de "amor desesperado pela vida": "Único remédio contra a angústia através da qual deslizamos lentamente para a morte, a explosão do riso seria uma explosão de vida" (MINOIS, 2003, p. 619).

Na sociedade midiatizada, revela-se falsa a ideia de que os conceitos de caricatura e paródia possam ser reduzidos a um ou outro suporte midiático. Os textos humorísticos já não precisam ser elaborados para um espaço fixo; necessitam, contrariamente, de dinâmica, ubiquidade, flexibilidade para serem aproveitados por diferentes mídias. A caricatura e a charge, por exemplo, há muito deixaram de ser textos localizados para as mídias impressas, sendo exploradas de diferentes formas pelas mídias eletrônicas. Com a paródia, percebe-se algo inverso: ela deixa o rádio, a TV e a internet para invadir as crônicas publicadas em jornais e revistas.

Independentemente do caráter textual, torna-se imprescindível considerar a natureza comunicativa do humor nas suas mais diferentes interpretações. Embora não esteja no centro da discussão, o antagonismo das perspectivas em torno do cômico e do riso em produtos

\footnotetext{
${ }^{9}$ A palavra caricatura vem do verbo italiano caricare, que significa carregar, pesar. Refere-se a uma representação plástica ou gráfica de uma pessoa, tipo, ação ou ideia interpretada voluntariamente de forma distorcida sob seu aspecto ridículo e grotesco (FONSECA, 1999, p. 28).
} 
midiáticos mostra o quanto é desafiador trazer um tema de caráter tão complexo para um cenário sociocultural contemporâneo marcado pelas diferenças identitárias e pelos processos de midiatização.

\section{CONSIDERAÇÕES FINAIS}

As diferenças identitárias foram uma recorrente fonte de referência na produção humorística. Vários teóricos trataram sobre o tema antes mesmo de o humor se tornar uma preocupação para as ciências humanas e sociais. De acordo com Propp (1992), podem ser cômicas não apenas as pessoas de uma comunidade diferente, mas também as da própria comunidade à qual pertencem, quando se distinguem das outras claramente em algo. Essa concepção aponta para o fato de que os temas do humor revelam questões importantes das sociedades envolvidas: desde os interesses dominantes, as atitudes e os valores relativos à identidade, até seus contrapontos, contradições e ambivalências.

O humor parece se valer da condição dinâmica das identidades culturais, criando alvos mutáveis e culturalmente inventados. Como nota Saliba (2002), a representação humorística é uma epifania da emoção: "Ela se dilui na vida cotidiana e só de vez em quando brilha e ilumina, como um intervalo de riso e de alegria na rotina dos ritmos repetitivos diários" (SALIBA, 2002, p. 29). Trazendo a questão para o plano das narrativas nacionais, o autor observa que cada imaginação produz sua peculiar representação humorística; cada uma forja suas peculiares línguas e falas cômicas, que se expressam nos estereótipos concisos, sintéticos e rapidamente inteligíveis, mas também cheios de subentendidos, de omissões, de silêncios e de "não ditos".

Como fenômeno sociocultural, Le Goff (2000) define o riso como uma prática social com seus próprios códigos, seus rituais, seus autores e seu palco. "Ele exige pelo menos duas ou três pessoas, reais ou imaginárias: uma que provoca o riso, uma que ri e outra de quem se ri" (LE GOFF, 2000, p. 65). A consideração do autor revela que o riso é eminentemente comunicacional e relacional, sua principal estratégia é a de aproveitar-se permanentemente do duplo sentido e da ambiguidade.

É comum detectar elementos universais e provincianos nos personagens humorísticos contemporâneos. Nesse contexto, torna-se relevante considerar como o humor midiático se apropria de discursos identitários e os massifica com um mapeamento das relações entre o imaginário popular e a cultura de massa. Historicamente, esses programas humorísticos aparecem e se popularizam tomando elementos da cultura popular solidamente implantados no cotidiano social. Maria Helena Ferrari (1994), em seu estudo Humor carioca como forma social, procura apreender o humor como uma nova forma de explicação e interpretação do mundo; não como uma oposição às formas convencionais, mas como uma forma diferente de construir uma ordem de valores. É aqui que a autora chega à noção de que humor é uma forma social, ou seja, uma forma de apreensão, de relacionamento com a realidade.

A cultura midiática tem seus subgêneros no próprio gênero humorístico, tendo em vista que as produções exibidas em diferentes plataformas podem se dividir em vários formatos (sitcom, seriado, programa independente, de auditório, com participação/interação do espectador, entre outros), os quais quase sempre recorrem à paródia e à caricatura na confecção de seus enredos. Ela também é constituída de hibridismos, cujos formatos estabelecem relações intersígnicas, mesclando a ficção com a realidade e migrando de uma mídia para outra de modo circular. Se, 
por um lado, observa-se que o monopólio das mídias no Brasil colabora para que a linguagem massiva seja pouco desenvolvida, com criatividade limitada; por outro, há de se reconhecer que a cultura midiática nacional, com sua identificação multicultural, fragmentada, desestabiliza o projeto de ordenação social, política, econômica e cultural contemporânea. E gêneros midiáticos como o humorístico não podem fugir dessa circularidade dos mundos da vida.

O estereótipo é um dos resultados da forma social representada pelo humor, tendo em vista que, se forem tomados os tipos caricaturais que as construções humorísticas exibem, os traços identitários são os aspectos mais evidenciados nos personagens. Sobre o tema, aliás, torna-se interessante aqui recorrer à noção de Ecléa Bosi (2004) de que, no processo de estereotipia, os padrões correntes interceptam as informações no trajeto rumo à consciência, apoderando-se da vida mental: "Nem sempre estamos dispostos à aventura da percepção: somos insensíveis e desatentos às coisas que povoam nosso mundo e, por isso, sofremos de uma perda, de um empobrecimento que nos faz capitular e enxergar através de mediações impostas" (BOSI, 2004, p. 115-6).

Os estereótipos de contextos mais globalizados ocupam seu espaço no humor midiatizado nacional, em personagens que exploram características bem conhecidas do universo popularmassivo, como a mentira, a vaidade, a ingenuidade, a avareza, a hipocrisia, o mau humor, a imoralidade, entre tantas outras que circulam no imaginário social brasileiro. Essas particularidades são reelaboradas simbolicamente em caricaturas, paródias, dramatizações, imitações, charadas, zombarias e mitificações referenciais que se hibridizam nos programas humorísticos com elementos culturais locais, nacionais e globais.

No Brasil, construiu-se o mito de que o humor está arraigado na cultura nacional ${ }^{10}$. É como se o cenário sociocultural, em horizonte público e privado, fortalecesse a vocação de um país para a comicidade. Na cultura midiática, uma das estratégias de captura da subjetividade dos espectadores foi a personificação de tipos sociais, talvez vinculada à noção de Buarque de Holanda (1998) da "cordialidade brasileira", que anunciava um comportamento de natureza intimista e familiar, avesso a relações institucionalizadas. Independentemente da veracidade ou não da premissa, é certo que alguns aspectos contribuem para essa representação: as gírias e expressões locais/regionais; e os diferentes sujeitos sociais identificados no território. As dimensões continentais do país colaboraram para o surgimento de identidades sociais diversas, e muitas delas se enraizaram na memória popular, criando o estereótipo, um dispositivo imprescindível para a comicidade.

O entendimento de que o humor presente na maior parte das produções tem no pastiche sua característica essencial não significa necessariamente uma perspectiva depreciativa. A celeridade das criações humorísticas impõe limites aos produtores na mesma proporção que abre os significados para o receptor. Este passa a ter papel proeminente em uma construção cômica menos engajada e mais suscetível de negociação de leituras, de usos e de apropriações. Nessa instância, o caráter descartável do humor pode ser atribuído ao próprio consumo repetitivo dessas produções, que não permite o amadurecimento entre um signo e outro.

O humor midiático encontrou na realidade social um abundante terreno para exagerar as diferenças/mitos regionais (gaúcho-"macho", carioca-malandro, paulista/mineiro-caipira,

\footnotetext{
${ }^{10} \mathrm{Um}$ dos entusiastas dessa ideia é um dos mais conhecidos humoristas do jornalismo impresso brasileiro, o escritor e cronista da Folha de S. Paulo José Simão (2007), que disseminou o conceito de que o "Brasil é o país da piada pronta".
} 
baiano-lento) e criar tipos caricatos que respondem por boa parte do anedotário nacional. E, no pensamento de Baczko (1985), é por meio dos imaginários sociais que as coletividades elaboram imagens de si e dos outros. Nessa linha de compreensão cultural, é possível dizer que as construções humorísticas identitárias se baseiam em fatores exteriores, facilmente reconhecidos, enrijecidos por uma perspectiva essencialista. E vale recorrer aqui ao pensamento de Barthes (2001) de que o mito retira o sentido que o real atribui às coisas, é uma fala despolitizada, sem a presença das relações sociais, em que não há o processo de estruturação da vida dos sujeitos. Ele existe de modo natural e consensual. Nesse processo de produção mítica, as ações humanas são reduzidas a uma dimensão destituída de complexidade, de contradições.

\section{REFERÊNCIAS}

ALBERTI, Verena. O riso e o risível na história do pensamento. Rio de Janeiro: Jorge Zahar Editor, 2002.

BACZKO, Bronislaw. Imaginação social. In: ENCICLOPÉDIA Einaudi. Lisboa: Imprensa Nacional/Casa da Moeda, 1985, p. 296-332. v. 5.

BAKHTIN, Mikhail. A cultura popular na Idade Média e no Renascimento: o contexto de François Rabelais. São Paulo: Edunb/Hucitec, 2002.

BARTHES, Roland. Mitologias. Rio de Janeiro: Bertrand Brasil, 2001.

BERGSON, Henri. O riso: ensaio sobre a significação da comicidade. São Paulo: Martins Fontes, 2001.

BOSI, Eclea. O tempo vivo da memória: ensaios de psicologia social. São Paulo: Ateliê Editorial, 2004.

BREMMER, Jan; ROODENBURG, Herman (Org.). Uma história cultural do humor. Rio de Janeiro: Record, 2000.

BUARQUE DE HOLANDA, Sérgio. O homem cordial. In: OLIVEIRA, Paulo de Salles (org.). Metodologia das Ciências Humanas. São Paulo: Hucitec, 1998.

BURKE, Peter. Fronteiras do cômico nos primórdios da Itália moderna. In: BREMMER, Jan; ROODENBURG, Herman (Org.). Uma história cultural do humor. Rio de Janeiro: Record, 2000. p. 93-114.

DRIESSEN. Henk. Humor, riso e o campo: reflexões da antropologia. In: BREMMER, Jan; ROODENBURG, Herman (Org.). Uma história cultural do humor. Rio de Janeiro: Record, 2000. p. 251-75.

ECO, Umberto. Pós-escrito a O nome da rosa. Rio de Janeiro: Nova Fronteira, 1985.

FERRARI, Maria Helena. Humor carioca como forma social. 1994. Tese (Doutorado em Comunicação) Programa de Pós-Graduação da Escola de Comunicação, Universidade Federal do Rio de Janeiro, Rio de Janeiro, RJ, 1994.

FONSECA, Joaquim da. Caricatura: a linguagem gráfica do humor. Porto Alegre: Artes e Ofícios, 1999.

FREUD, Sigmund. Os chistes e sua relação com o inconsciente. Rio de Janeiro: Imago Editora, 1977.

GARCÍA CANCLINI, Néstor. A globalização imaginada. São Paulo: Iluminuras, 2003.

GUREVICH, Aaron. Bakhtin e sua teoria do carnaval. In: BREMMER, Jan; ROODENBURG, Herman (Org.). Uma história cultural do humor. Rio de Janeiro: Record, 2000. p. 83-92. 
LE GOFF, Jacques. O riso na idade média. In: BREMMER, Jan; ROODENBURG, Herman (Org.). Uma história cultural do humor. Rio de Janeiro: Record, 2000. p. 65-82.

LUNARDELLI, Fatimarlei. Ô psit!: o cinema popular dos trapalhões. Porto Alegre: Artes e Ofícios, 1996. MARTíN-BARBERO, Jesús. Dos meios às mediações: comunicação, cultura e hegemonia. Rio de Janeiro: UFRJ, 2003.

MINOIS, Georges. História do riso e do escárnio. São Paulo: Unesp, 2003.

POSSENTI, Sírio. Humor e estereótipos femininos. [S.I]: [s.n.], 2005. Disponível em: www.congressoaled2005. puc.cl/pdf/possenti.pdf. Acesso em: 10 jan. 2015.

POSSENTI, Sírio. Os humores da língua: análises linguisticas das piadas. Campinas: Mercado das Letras, 1998.

PROPP, Vladimir. Comicidade e riso. São Paulo: Ática, 1992.

ROCHA, Simone Maria. A "mineiridade" em questão: do discurso mítico ao discurso midiático. 2003. Tese (Doutorado em Comunicação) - Programa de Pós-Graduação da Escola de Comunicação, Universidade Federal do Rio de Janeiro, Rio de Janeiro, RJ, 2003.

SALIBA, Elias Thomé. Raízes do riso: a representação humorística na história brasileira - da Belle Époque aos primeiros tempos do rádio. São Paulo: Companhia das Letras, 2002.

SALOMÃO, Mozahir. Jornalismo radiofônico e vinculação social. São Paulo: Annablume, 2003.

SILVA, Tomaz Tadeu (Org.). Identidade e diferença: a perspectiva dos estudos culturais. Petrópolis: Vozes, 2007.

SIMÃO, José. No país da piada pronta. São Paulo: Editora do Bispo, 2007.

SKINNER, Quentin. Hobbes e a teoria clássica do riso. São Leopoldo (RS): Editora Unisinos, 2002.

SOUSA SANTOS, Boaventura de. Um discurso sobre as Ciências na transição para uma ciência pós-moderna. Estudos Avançados, São Paulo, v. 2, n. 2, p. 46-71, 1988.

WOODWARD, Kathryn. Identidade e diferença: uma introdução teórica e conceitual. In: TADEU DA SILVA, Tomaz (Org.). Identidade e diferença: a perspectiva dos estudos culturais. Petrópolis, RJ: Vozes, 2007. p. 7-72.

\section{Sobre o autor:}

Ricardo Pavan: Jornalista, docente do Curso de Jornalismo e do PPGCOM da Faculdade de Informação e Comunicação da Universidade Federal de Goiás. E-mail: pavan.ufg@gmail.com, Orcid: http://orcid.org/0000-0001-6226-1562 